\title{
Smoking, vaping and hospitalization for COVID-19
}

\author{
Konstantinos Farsalinos ${ }^{1}$, Anastasia Barbouni ${ }^{1}$, Raymond Niaura ${ }^{2}$ \\ 1 University of West Attica \\ 2 New York University
}

\section{Abstract}

The study presents an analysis of the current smoking prevalence among hospitalized patients with COVID-19 in China, compared to the population smoking prevalence in China (52.1\% in males and $2.7 \%$ in females). We identified 5 studies examining the clinical characteristics of hospitalized COVID-19 patients that presented data on the smoking status. The expected number of smokers was calculated using the formula Expected smokers $=($ males $\times 0.521)+($ females $x$ 0.027). An unusually low prevalence of current smoking was observed among hospitalized COVID-19 patients (10.2\%, 95\% Cl: 8.7-11.8\%) compared to the expected prevalence based on smoking prevalence in China (31.3\%, 95\% Cl: 29.033.6\%; z-statistic: $17.89, \mathrm{P}<0.0001)$. This preliminary analysis does not support the argument that current smoking is a risk factor for hospitalization for COVID-19, and might suggest a protective role. The latter could be linked to the downregulation of ACE2 expression that has been previously known to be induced by smoking. No studies recording e-cigarette use status among hospitalized COVID-19 patients were identified. Thus, no recommendation can be made for e-cigarette users. Keywords. SARS-CoV-2, COVID-19, ACE2, expression, susceptibility, smoking, hospitalization, electronic cigarette.

\section{Introduction}

There is a lot of speculation about the effects of smoking on Corona Virus Disease 2019 (COVID-19). Smoking increases susceptibility to respiratory infections and media reports suggest that it may increase the risk of being infected with acute respiratory syndrome coronavirus 2 (SARS-CoV-2), the virus responsible for COVID-19. SARS-CoV-2 is known to use the angiotensin converting enzyme 2 (ACE2) as a receptor for cell entry, and there is evidence that smoking downregulates ACE2 expression in the lung and other tissues. ${ }^{1}$ China has a high prevalence of smoking (27.7\%), much higher among males $(52.1 \%)$ 
than females $(2.7 \%){ }^{2}$ The purpose of this study was to examine the prevalence of current smoking among Chinese hospitalized cases with COVID-19 relative to the population prevalence of current smoking in China.

\section{Methods}

To examine how the prevalence of smoking among hospitalized COVID-19 compares to the smoking prevalence of the population, we searched the literature and identified 5 studies examining clinical features of hospitalized COVID-19 patients in China which included data about the smoking status. ${ }^{3-7}$ Prevalence of smoking among hospitalized patients was compared with the expected prevalence which was calculated based on the population smoking prevalence and the gender of patients, using the formula:

Expected smokers $=($ males $\times 0.521)+($ females $\times 0.027)$

\section{Results}

Findings are presented in Table 1. From a total 1546 hospitalized COVID-19 cases analyzed in the 5 studies included, $58.0 \%$ were males and $42.0 \%$ were females. The prevalence of current smoking was $10.2 \%$ (95\% Cl: 8.6-11.7\%). However, the calculated expected prevalence of current smoking, considering the population prevalence in China was 31.3\% (95\% Cl: 29.0-33.6\%). The difference was statistically significant according to z-test (z-statistic: 17.89, P<0.0001). 
Table 1. Gender and smoking prevalence among hospitalized COVID-19 patients, and expected number of smokers based on population prevalence of smoking in males $(52.1 \%)$ and females $(2.7 \%)$ in China.

\begin{tabular}{|c|c|c|c|c|c|c|c|}
\hline & $\begin{array}{l}\text { Hospitalized } \\
\text { cases }\end{array}$ & Males & Females & $\begin{array}{l}\text { Expected } \\
\text { current } \\
\text { smokers (1) }\end{array}$ & $\begin{array}{l}\text { Expected } \\
\text { current } \\
\text { smokers }\end{array}$ & $\begin{array}{l}\text { Hospitalized } \\
\text { Current } \\
\text { smokers }\end{array}$ & $\begin{array}{l}\text { Hospitalized } \\
\text { Current } \\
\text { smokers }\end{array}$ \\
\hline & $\mathrm{N}$ & $\mathrm{n}$ & $\mathrm{n}$ & $\mathrm{n}$ & $\%(95 \% \mathrm{Cl})$ & $\mathrm{n}$ & $\%(95 \% \mathrm{Cl})$ \\
\hline $\begin{array}{l}\text { Guan } \\
\text { etal. }\end{array}$ & 1096 & 637 & 459 & 344 & $\begin{array}{l}31.4 \text { (28.7- } \\
34.1)\end{array}$ & 137 & $\begin{array}{l}12.5 \text { (10.5- } \\
14.5)\end{array}$ \\
\hline $\begin{array}{l}\text { Zhou } \\
\text { et al. }\end{array}$ & 191 & 119 & 72 & 64 & $\begin{array}{l}33.5(26.8- \\
40.2)\end{array}$ & 11 & $5.8(2.5-9.1)$ \\
\hline $\begin{array}{l}\text { Zhang } \\
\text { et al. }\end{array}$ & 140 & 71 & 69 & 39 & $\begin{array}{l}27.8(20.4- \\
35.2)\end{array}$ & 2 & $1.4(0.0-3.3)$ \\
\hline $\begin{array}{l}\text { Liu et } \\
\text { al. }\end{array}$ & 78 & 39 & 39 & 21 & $\begin{array}{l}27.4 \text { (17.5- } \\
37.3)\end{array}$ & 5 & $\begin{array}{l}6.4(0.1- \\
11.8)\end{array}$ \\
\hline $\begin{array}{l}\text { Huang } \\
\text { et al. }\end{array}$ & 41 & 30 & 11 & 16 & $\begin{array}{l}38.8(16.9- \\
45.3)\end{array}$ & 3 & $\begin{array}{l}7.3(0.0- \\
15.3)\end{array}$ \\
\hline Total & 1546 & 896 & 650 & 484 & $\begin{array}{l}31.3(29.0- \\
33.6)\end{array}$ & 158 & $\begin{array}{l}10.2(8.6- \\
11.7)\end{array}$ \\
\hline
\end{tabular}

z-statistic: 17.89, P < 0.0001. (1) Expected number of smokers was calculated based on the Table

\section{Discussion}

The current study examined for the first time the prevalence of current smoking among hospitalized patients with COVI-19 in China and compared it with the expected prevalence based on the population smoking prevalence. Care was taken to consider the large difference between genders, with current smoking being substantially more prevalent among Chinese males than females. An unusually low prevalence of current smoking among hospitalized COVID-19 cases in China was observed when considering the population smoking prevalence. The true prevalence of current smoking among 
hospitalized COVID-19 cases presented in 5 studies was approximately one-third the expected prevalence. This preliminary analysis, assuming that the reported data are accurate, does not support the argument that current smoking is a risk factor for hospitalization for COVID-19, and might even suggest a protective role. The latter could be linked to the downregulation of ACE2 expression that has been previously known to be induced by smoking. However, other factors, such as socioeconomic status, should be considered in examining the access of smokers with COVID-19 to hospital care. Furthermore, disease progression, complications and death among hospitalized COVID19 patients who are current smokers need to consider other comorbidities, such cardiovascular disease, which are risk factors for adverse COVID-19 outcomes and are more prevalent among current smokers. Currently available evidence does not allow for a multivariate analysis adjusted for such factors. It remains unclear whether smoking per se or other factors related to comorbidities may be responsible for an adverse outcome. No studies recording e-cigarette use status among hospitalized COVID-19 patients were identified. Thus, no recommendation can be made for e-cigarette users.

\section{References}

1. Oakes JM, Fuchs RM, Gardner JD, Lazartigues E, Yue X. Nicotine and the reninangiotensin system. Am J Physiol Regul Integr Comp Physiol. 2018 Nov 1;315(5):R895R906. doi: 10.1152/ajpregu.00099.2018.

2. Parascandola M, Xiao L. Tobacco and the lung cancer epidemic in China. TransI Lung Cancer Res. 2019 May;8(Suppl 1):S21-S30. doi: 10.21037/tlcr.2019.03.12.

3. Guan WJ, Ni ZY, Hu Y, Liang WH, Ou CQ, He JX, Liu L, Shan H, Lei CL, Hui DSC, Du B, Li LJ, Zeng G, Yuen KY, Chen RC, T ang CL, Wang T, Chen PY, Xiang J, Li SY, Wang JL, Liang ZJ, Peng YX, Wei L, Liu Y, Hu YH, Peng P, Wang JM, Liu JY, Chen Z, Li G, Zheng ZJ, Qiu SQ, Luo J, Ye CJ, Zhu SY, Zhong NS; China Medical Treatment Expert Group for Covid-19. Clinical Characteristics of Coronavirus Disease 2019 in China. N EngIJ Med. 2020 Feb 28. doi: 10.1056/NEJMoa2002032.

4. Zhou F, Yu T, Du R, Fan G, Liu Y, Liu Z, Xiang J, Wang Y, Song B, Gu X, Guan L, Wei Y, Li H, Wu X, Xu J, Tu S, Zhang Y, Chen H, Cao B. Clinical course and risk factors for mortality of adult inpatients with COVID-19 in Wuhan, China: a retrospective cohort study. Lancet. 2020 Mar 11. pii: S0140-6736(20)30566-3. doi: 10.1016/S0140-6736(20)30566-3.

5. Zhang لע, Dong X, Cao YY, Yuan YD, Yang YB, Yan YQ, Akdis CA, Gao YD. Clinical characteristics of 140 patients infected with SARS-CoV-2 in Wuhan, China. Allergy. 2020 Feb 19. doi: 10.1111/all.14238.

6. Liu W, Tao ZW, Lei W, Ming-Li Y, Kui L, Ling Z, Shuang W, Yan D, Jing L, Liu HG, Ming 
$\mathrm{Y}, \mathrm{YiH}$. Analysis of factors associated with disease outcomes in hospitalized patients with 2019 novel coronavirus disease. Chin Med J (Engl). 2020 Feb 28. doi:

10.1097/CM9.0000000000000775.

7. Huang C, Wang Y, Li X, Ren L, Zhao J, Hu Y, Zhang L, Fan G, Xu J, Gu X, Cheng Z, Yu T, Xia J, Wei Y, Wu W, Xie X, Yin W, Li H, Liu M, Xiao Y, Gao H, Guo L, Xie J, Wang G, Jiang R, Gao Z, Jin Q, Wang J, Cao B. Clinical features of patients infected with 2019 novel coronavirus in Wuhan, China. Lancet. 2020 Feb 15;395(10223):497-506. doi: 10.1016/S0140-6736(20)30183-5. 